may be regularly spaced or form highly shattered narrow zones concentrated chiefly in the central area of the pebbles, and similarly orientated directions of cracking can be traced for many yards in adjacent boulders although the matrix is not visibly affected. Where the pebbles are subordinate to a sandy matrix no cracking occurs.

The patterns developed in individual pebbles may be conjugate fractures with an average angle of $20^{\circ}-30^{\circ}$, one set of parallel cracks agreeing in orientation with the mean bisectrix of the conjugate set or a combination of both. These patterns compare with the laboratory experiments on the compression of rock in the brittle régime. ${ }^{4}$. Under such compression rocks are brittle, and rupture is expressed in extension fractures parallel to the major stress direction associated with acute-angled wedge fractures.

Numerous small shear zones with slickensided surfaces and wrench displacement are prominent in both conglomerate and sandstone horizons, and these have an orientation parallel or oblique to conspicuous trends of cracking. The orientation of the shear zones falls into two sets the bisectrix of which approximates to the direction of single cracking in pebbles mentioned above. The structures described are the product of the main stresses responsible for the fault and are not secondary structures resulting from the movements on the fault.

The direction which corresponds to the maximum of single cracks and bisectrices of conjugate cracks and shear zones is therefore taken, by analogy with laboratory behaviour of similar brittle materials, to be the direction in which the principal stress acted. This direction is north-west-south-east, almost at right angles to the trend of the Highland Boundary Fault.

The investigation so far reveals a definite pattern to the tectonic structures in the Lower Old Red Sandstone commensurate with horizontal compression of the rocks in a north-west-south-east direction, as in a vice, thus confirming the reverse fault theory of origin.

Department of Geology, Queen's College,

University of St. Andrews, Dundee.

${ }^{1}$ Anderson, J. G. C., Trans. Roy. Soc. Edin., 61, Pt. 2, 479 (1947). ${ }^{2}$ Anderson, E. M., The Dynamics of Faulting (Edinburgh, 1951).

${ }^{3}$ du Toit, A. L., Trans. Geol, Soc, Edin., 8, Pt. 3, 315 (1905).

- Griggs, D., and Handin, J., Geol. Soc. Amer. Mem., 79, 347 (1960).

\section{Post-Glacial Sea-Levels}

FIG. 1 compares eustatic data from New Zealand with a generalized eustatic curve calculated from raised strandlines in Sweden and Norway ${ }^{1}$. The Fennoscandian region is undergoing isostatic rebound initiated by the retreat and melting of the Fennoscandian ice-cap, so that the Post-glacial raised strandlines owe their positions to the combination of two effects, changes in both land-and sea-level. The basic assumption behind the calculated eustatic curve (Fig. 1) is that the rates of isostatic rebound have been proportional from place to place-the raised strandlines used being from areas between Sauramo's Finniglacial and Gotiglacial hingelines, ${ }^{2,3}$.

Details of the calculations used by Dr. H. R. Thompson, biometrician of the Applied Mathematics Laboratory, New Zealand Department of Scientific and Industrial Research, and of the data selected for

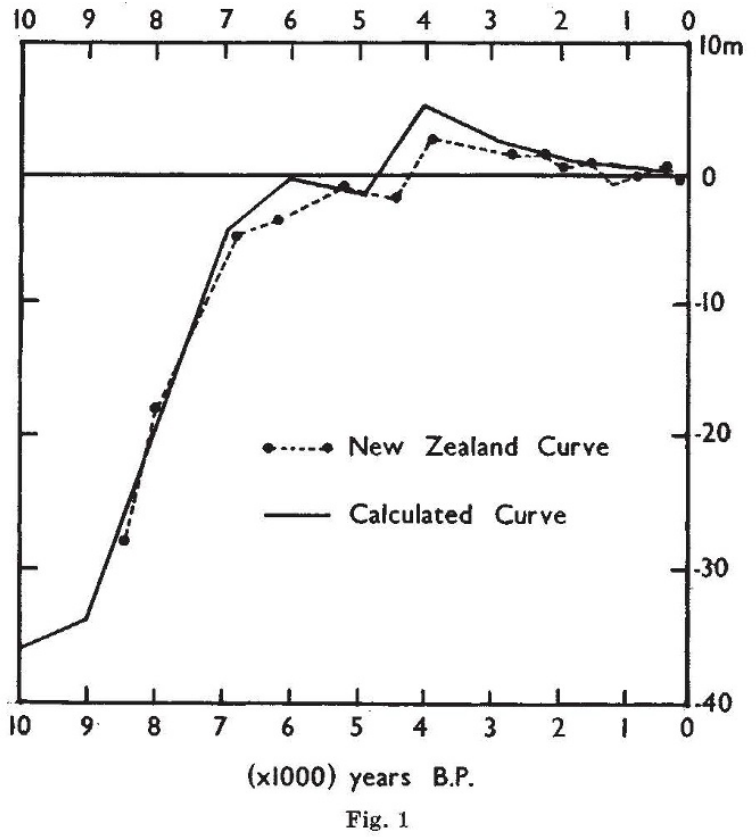

the New Zealand curve, will be published shortly in the N.Z. Journal of Geology and Geophysics. Note that some slight corrections have been made to that portion of the New Zealand curve younger than 4,000 years B.P. (compare with that given by Schofield ${ }^{4,5}$ ).

The calculated curve agrees with a Post-glacial high sea-level of about 4,000 years ago. It is also similar to the curves of Godwin et al. ${ }^{6}$ and McFarlan ${ }^{7}$ in that following the initial, rapid, Post-glacial rise, sealevel reached the present level 5-6,000 years ago. Both the calculated and New Zealand curves parallel Fairbridge' ${ }^{8}$ curve but differ in detail, the most important being the absence of his sea-level 'highs' of $-15 \mathrm{~m}$., 9,000 years ago and $+3-4 \mathrm{~m}$. of 5-6,000 years B.P.

\section{J. C. Schofield}

New Zealand Geological Survey, Otahuhu, Auckland.

1 Anderson, B. G., N.G.U., 210 (1960).

2 Sauramo, M., Bull. Comm. Geol. Finland, 125, 39 (1939).

3 Sauramo, M., Ann. Acad, Sci. Fennicae, AIII, 44 (1955).

${ }^{4}$ Schofield, J. C., Nature, 185, 836 (1980).

${ }^{5}$ Schofield, J. C., N.Z. J. Geol. Geophys., 3, 467 (1960).

${ }^{6}$ Godwin, H., Suggate, R. P., and Willis, E. H., Nature, 181, 1518 (1958).

'MeFarlan, E., Geol. Soc. Amer. Bull., 72, 129 (1961).

${ }^{8}$ Fairbridge, R. W., in Ahrens, L. H., et al., Physies and Chemistry of the Earth. 4, 99 (1961).

\section{Isotopic Ages from Some Spitsbergen Rocks}

IsoTopIC ages by potassium - argon and rubidium strontium methods have been measured on some Spitsbergen rocks, in the hope of contributing to the Mid-Palæozoic time-scale and to the understanding of local geological history ${ }^{1}$. Rubidium, strontium and argon measurements were made by stable isotope dilution analysis, except for York's figure, which was by total volume (argon) measurement. The potassium measurements were made by flrme photometer.

The following specimens were analysed, and the results are given in Tables 1 and 2 . 